УДК: 811.0-7.08-001

Т. А. Давиденко

\title{
ІНШОМОВНІ ЛЕКСЕМИ В ЖІНОЧІЙ ПРОЗІ К. ХХ - П. ХХІ сТ.: СПЕЦИФІКА ФУНКЦІОНУВАННЯ, СТИЛІСТИЧНІ ФУНКЦЇ̈
}

Давиденко Т. А. Іншомовні лексеми в жіночій прозі к. XX - п. XXI ст.: специфіка функціонування, стилістичні функції.

У статті розглянуто іншомовну лексику в мові прозових творів Є. Кононенко, М. Матіос, С. Майданської, простежено іiі роль у розкритті авторського задуму, індивідуалізації й етнографічній ідентифікації героїв прозового твору, встановлено стилістичні функції чужомовних елементів.

Ключові слова: жіноча проза, іншомовна лексика, стилістична функція, лексикосемантична група, транслітерований чужомовний елемент.

Давыденко Т. А. Иноязычные лексемы в женской прозе к. XX - п. XXI ст.: особенности функционирования, стилистические функции

В статье рассмотрено иноязычную лексику в языке женской прозе Е. Кононенко, М. Матиос, С. Майданской, рассмотрено ее роль в раскрытии авторской идеи, 
индивидуализации и этнографической идентификации героев прозаических произведений, определены ее стилистические функции.

Ключевые слова: женская проза, иноязычная лексика, стилистическая функция, лексико-семантическая группа, трансформированный элемент.

Davydenko T. A. Foreign language lexical area in the women's prose e. XX - b. XXI centuries: peculiarity of functioning, stylistic functions

Foreign language lexical area in literary works of Y. Kononenko, M. Matios, S. Majdanska is observed. Also its role is established in the showing of author's intention, heroes` individualization and ethnographical identification, stylistic functions of foreign language lexical area are determined.

Key words: women's prose, foreign language lexical area, stylistic function, vocabulary-semantic group, transformed component.

Протягом останніх десятиріч під впливом мовних і позамовних чинників лексика української мови зазнала значного оновлення та збагачення. Особливо активно ці тенденції простежуються на групі запозиченої лексики. Найповніше і найяскравіше іншомовні лексеми, різнотипні за структурою та семантикою, спроектовані в художнє мовлення. Жіноча проза к. XX п. XXI ст. активно апробує різноманіття іншомовних слів. Грунтовне вивчення лексики іншомовного походження здійснене І. Білодідом, А. Коваль, А. Москаленком, В. Сімонок, Д. Шульгою. Стилістичне наповнення іншомовної лексики є об'єктом наукових інтересів І. Дегтярьової, Л. Кравець, С. Мельник та ін. Однак досліджень, присвячених вивченню структурного та стилістичного потенціалу іншомовної лексики в сучасній жіночій прозі, поки бракує.

Мета статті - визначити стилістичні потенції іншомовної лексики (IЛ) у творах представниць української жіночої прози.

Літературна спадщина українських письменниць репрезентує функціонування іншомовних елементів, які інтегрують у різні мовні рівні фонологічний, словотвірний, лексичний і синтаксичний, вступаючи в певні лексичні та семантичні зв'язки. «Лексика іншомовного походження в сучасній художній літературі стає, насамперед, засобом стилізації, створення своєрідного «мовного колориту», інфільтрації іншомовної культури та мови в українську дійсність» [1, с. 187].

У сучасній лінгвістиці іншомовні лексеми розподіляють на дві групи: варваризми та вкраплення. Так, варваризм - це «іншомовне або створене за іншомовним зразком слово чи зворот, що зберігає структурні ознаки чужих мов, по-різному пристосовуючись до фонетики, морфології української мови» [6, с. 62]. Вкраплення тлумачать як «уведений у твір 3 певною змістовною або стилістичною метою уривок іншомовного тексту» [6, с. 82]. На нашу думку, більш доцільним $є$ використання терміна «вкраплення», оскільки в ньому відображені лінгвостилістична квінтесенція іншомовної лексеми та спосіб їі введення в українськомовну канву прозового твору.

У нашому дослідженні первинною функцією ІЛ є власне номінативна, 
якою послуговуються для прямої номінації денотатів. У художніх творах вона допомагає визначити такі лексико-семантичні групи (ЛСГ):

I. Номінація «Особа. Характеристика особи»:

а) ідентифікація особи на ім'я чи / i прізвище, напр.: Лариса роздивлялась візитівку. Так, Alex Gayer..., далі знов-таки німецьькюю мовою було зазначено рід його заняття, Лариса не знала тої мови (С. Кононенко); Iот серед мряки, дощу, домашніх завдань $i$ недописаних статей пролунав міжміський телефон. - Is it Nela? I'm Juren Christensen, звучав упевнений бадьорий голос (Є. Кононенко).

Численними є ілюстрації використання ІЛ при звертанні зі вказівкою на міжособистісні стосунки персонажів, що можуть бути як офіційними, напр.: Не бійся, domnule Мігаю. Нічого не трафилося (М. Матіос), doтпиle - пан [3, с. 446]; - Dоатпо Матроно! - сказав Лупул, коли стіл був заставлений полумисками, i зсадив говірливу дитину з колін (М. Матіос), doатпо - пані, звертання [3, с. 446], так і неофіційними, напр.: Мати змучено слухає, як дочка вимовляє: "Yes, my dear! OK, my darling!" (Є. Кононенко). Yes, my dear! OK, my darling - Так, мій любий! Добре, мій дорогий [2]. ІЛ при цьому ілюструє як позитивне ставлення, напр.: - My baby! My teddy-bear! - вуркоче гостя (С. Кононенко). My baby! My teddy-bear - моє маленьке! Моє м'яке ведмежатко [2], так і негативне, напр.: Аби він не оиінив мене належним чином, чи назвала б я його ducon, сучий син, як Анна Гавальда назвала видавця з Лівого берега? (Є. Кононенко), ducon - мудак [7];

б) якісна характеристика людини, напр.: $A$ він накопить грошей, відикодує збитки й далі иукатиме жінку, - mу, єдину, THE VERY WOMAN (Є. Кононенко), the very woman - особлива жінка [2]; Але й побляклій від тривалих пошуків Галі усміхнулося щзастя: зустрівся пеvеr married youthfull Englishmen with own house not far from Manchester, якому Галя відразу припала до душі (Є. Кононенко). Never married youthfull Englishmen with own house not far from Manchester - неодружений, молодий англієць 3 власним будинком недалеко від Манчестера [2];

в) оцінка рівня освіченості, яка може бути як високою, напр.: $A$ Неля уявила старий будинок, на зразок описаного Андерсоном в однойменній казиі, картини, икіряні крісла, великий письмовий стіл і книюккові шафи від nідлоги до стелі. Well-educated woman? (Є. Кононенко) well-educated womanдобре освічена жінка [2], так і мати абсолютно протилежне значення, напр.: - Він був дисидентом? - запитав Рональд. - Oh, how stupid you are! - не стримала роздратування Оксана. - Дарма щуо директор економіки! (Є. Кононенко). Oh, how stupid you are - О, який же ж ти дурний [2];

г) соціальна характеристика персонажів, напр.: То був охоронецьь Петя, найсимпатичніший з ӥхнього Security (Є. Кононенко), security - охорона [2, с. 522]; Михайло збіг згори щуе до полудня. Навіщуось узяв у Марї спухлу від плачу дитину - $i$ пішов до primara (М. Матіос), primar - сільський 
голова, двірник [3, с. 1081];

г) національна належність, напр.: - Эт кто та-акие? Па-аляки? Чехи? дивувалися у кав'ярні, а вони навмисно вживали галицькі звороти, шуоб більше бути схожими на іноземиів (Є. Кононенко); Він відповів саме їй, хоча й отримав багато листів від молодих $і$ не дуже полячок. A тут лист від «Russion woman», про щуо він $і$ мріяти не смів (Є. Кононенко), russion womanросійська жінка [2]; Могла б сісти на нього - мала посвідчення "Volksdeutsche», та на иеей раз не скористалася своїми «привілеями» (C. Майданська), volksdeutsche - німці, які проживали на окупованих у 19391943 рр. радянськими військами територіях (С. Майданська).

II. Номінація «Літературні твори. Друковані видання»:

а) назви літературних творів, напр., віршів: - Biн уміє говорити французькою $i$ знає напам'ять REMIND ME NOT лорда Байрона (Є. Кононенко); А Васька... був типовий радянський алкоголік-інтелігент... по першій він читав Пастернака... По другій - «My soul is dark» мовою оригіналу (Є. Кононенко), казок, напр.: Оповідь про сапку, n'ять кілометрів пішки до електрички, жіночу гордість та паскудну украӥнську селянську культуру набула в їхній маленькій родині масштабів притчі, ияю історію їи розповіли щуе раніше, ніж «Сказку о мертвой царевне» (С. Кононенко); Але син ивидко забував російську, забув паскудне «хохли-козли», але забув $i$ «Сказку про царя Салтана», ц̌ «Конька-Горбунка» (С. Кононенко). Поодинокими є ілюстрації номінації новел: Далі новелка «The Opel Touch». Тежс душевно (Є. Кононенко);

б) назви друкованих видань, напр., журналів: $A$ поки у кожного на тарілці лежить по цілій курці з рум'яною шкірочкою... саме так радить серверувати стіл журрнал "Elle» (Є. Кононенко); Дочка почала голосно ридати. Батько пішов... читати свіже число жсурналу «Наука и жсизнь» (С. Кононенко), книг: Позбувиись у бібліотецуі книюкок обов'язкового позакласного читання про “Как закалялась сталь» $i$ «Молоду гвардію», розмахуючи порожньою течкою, пустився розгонистим кроком... (С. Майданська).

III. Номінація «Установи», зокрема:

а) навчальні заклади, напр.: Серед дітей був уже й батько Зеновія учень шостого класу Периої хлоп'ячої гімназії, була й мати Делії учениия третього класу "Liceul Ortodox» - найпрестижнімої дівочой гімназї (С. Майданська); Найкращуе вступити до колишньої політехніки «Technische Fachkurse», а теперішніх $i$ неодмінно на архітектуру... (С. Майданська);

б) компанії, напр.: 18 листопада Олександр Чеканчук прийшов до офісу Украӥнської філї̈ фундаџї GIFTED CHILD INTERNATIONAL за годину до початку робочого дня (Є. Кононенко), Gifted Children International - Міжнародний фонд підтримки обдарованих дітей [2]; Ti, 
хто літає за свої, здебільшого послуговуються «Авіалініями Украйни» або польською компанією LOT (Є. Кононенко);

в) розважальні заклади, напр.: ресторани: $A$ в ресторані «Astoria» музиканти вже настроювали інструменти, щуоб знову заграти танго «Dami mina ta» (С. Майданська), театри: Ларочка... сама б $і$ не здогадалася иукати Додів тайник, та після такого «компромату» гастрольна дорога 3 України в усі «Metropolitan Opera», "Grand Opera», «La Scala», мов тоті Кафчині ворота, зачинилася для неї назавжди (С. Майданська);

г) торговельні заклади, напр., магазини: $A$ изе, між іниим, подарунок Мар'яни! Мій заповітний колір: темно-вичневий. Купила в Duty free y Франкфурті... (Є. Кононенко).

IV. Номінація «Страви»:

а) напої, напр.: У Каліфорнї в дев'яностому розлили top-cabernet! (Є. Кононенко), top-cabernet - каберне найвищої якості [2]; Після каліфорнійського tор-wine Лариса $і$ Сашко Риженко зсунули поряд ліжка в номері коломийського готелю (С. Кононенко), top-wine- вино найвищої якості [2]; Потім якось разом, одним духом випивии охололе «еsрresso», втрьох підвелися з-за столу (С. Майданська);

б) другі страви, напр.: - Скажи, тобі подобається наше західне життя? - запитує Жан-Марк за вечерею в маленькому ресторанчику, де їм подали poulard a la ficele (С. Кононенко); Всі вони вилежувалися на його диванах... А також натхненно поӥдали його холостяџький fast food (Є. Кононенко).

V. Номінація «Свята»:

а) іншомовні елементи з орієнтацією на традиційні державні свята, пов'язані з періодом СССР, напр.: Син, продовжуючи сімейну традицію, також робив військову кар'єру.,, а дочка влаштовувала батькові «празднички»: на «8 Марта», на "1 Мая", на «День Победы», на «Октябрьские», на «День Советской Армии и Военно-Морского Флота», на «День Конституции» $i$ на «Новый год» (С. Майданська); Улюблені «Октябрьские» $i$ «ень Победы» святкувалися ледь не щзодня, подейкували, правда, щуо генерал ніколи й поруху не занюхав, його службба під час війни була суціль оповита «государственной mайной» (С. Майданська) чи на сімейні, напр.: - За кого ти мене маєш? Підкладати дівчат! Скоро матимемо Wedding (Є. Кононенко) [2];

б) релігійні свята, що відзначають за кордоном, напр.: A потім прийиов день - то був другий день григоріанського Різдва, Boxing Day, коли годилося б відзначати сорок днів по Мар'яні Хрипович (Є. Кононенко) і у нас, напр.: $A$ поки треба прац̧ювати й прац̧ювати, щуоб заслужити собі справжній Метrу Christmas (Є. Кононенко), Merry Christmas - Різдво [2].

VI. Номінація «Товарні знаки. Торгівельні марки», напр.: Риженко дає друзям у дорогу блок пива «Виdweiser» $i$ палиџю салямі (Є. Кононенко); Офіціант приносить гарячі бутерброди $i$ прозорі кухлі з окропом, де 
плаває пакетик чаю «Lipton» (С. Кононенко).

VII. «Написи-кліше - заборона дії», напр.: 3 пагорба спускалися іншою дорогою, зненацька перед нами виріс будинок,.. на воротах висіла табличка $з$ написом: «Во дворе злая собака!», $і$ справд $і$ - у величезній залізній клітці, з кута в кут, збуджено поскімлюючи, бігала вівчарка ... (С. Майданська); Він [Олександр Риженко - Т. Д.] палить цицарку, хоча на стіні переконливий плакат NO SMOKE (С. Кононенко); NO SMOKE- не палити [2].

VIII. Іншомовні елементи, в основі яких є відношення до ознаки:

а) кольору, напр.: А шоб Мар яна не задирала носа, ніби тільки вона здатна робити дорогі подарунки, я їи теж подарувала фірмові шкіряні рукавички! Ï̈ заповітного кольору marine (Є. Кононенко), marin - колір морської хвилі [7, с. 153]; I не руде, і не біляве, а саме таке, кольору feuille morte, як у незрівняної Ірен Форсайт, однієї з найяскравіших літературних красунь (Є. Кононенко), feuille morte - опале листя [7];

б) матеріалу, напр.: То його очі впали на ручний годинник, щзо лежить поряд! На ремінці, який він сьогодні поставив, написано Gепиіпе leather. Genuine-imitated - uе 3 репертуару Мар'яни Хрипович (Є. Кононенко), genuine leather - натуральна (справжня) шкіра, genuineimitated - справжнє-підроблене [2]; Нічого в світі кращзого немає за genuine, немає нічого жахливішого за imitated (Є. Кононенко);

в) вартості, напр.: - Аж розум відібрало, коли до тебе в руки прийшли дешеві баби зі Сходу! - I can ‘t say it was cheap... - пролопотів Антоніус (Є. Кононенко). I can't say it was cheap - не можу сказати, що це було дешево [2];

г) місця виготовлення, напр.: Чуючи непохитним нюхом забави, вони випорпували кінські та людські черепи.., щуоб тепер похизуватися своїм скарбом, а часом, скориставшись нагодою, обміняти на портяниці «Made in USA» (С. Майданська).

Окрім власне номінативної функції іншомовні елементи виконують такі стилістичні функщії:

а) маркера для визначення рівня мовної культури персонажа. Так, події роману «Імітація» Є. Кононенко відбуваються в одній українській філії міжнародної фундації підтримки обдарованих дітей, шефом якої працює американець Роджер Біст, саме тому і для його мови, i для мови його співробітників притаманний україно-англійський білінгвізм, напр.: Again private talks? - весело запитує шеф украӥнської філї GIFTED CHILD INTERNATIONAL Роджер Біст, заходячи до холу фундації. Private, if you want, - люто відповів Чеканчук (С. Кононенко). Again private talks? - Знову приватна розмова? Private, if you want - приватна, якщо хочеш (Є. Кононенко). Вимушені іншомовні комунікації показують штучність мовної ситуації, яка ілюстрована контекстом;

б) реалістичного відтворення особливостей усного мовлення () Т. А. Давиденко, 2013. 
персонажів. Досить продуктивною групою є чужомовні словосполучення та речення на синтаксичному рівні, які утворюють такі складні комунікативні структури, як монологи та діалоги, що пояснюється прагненням зберегти національну ідентичність їхніх героїв. Так, наприклад, С. Майданська у повісті «Провідна неділя» вводить російськомовного героя - відставного генерала КДБ, тому його репліки подано саме російською мовою, напр.: Так прибравиися, виходив на терасу, щуо у дні нескінчених револючійних свят слугувала йому за трибуну, $i$, звертаючись до уявної колони демонстрантів, гукав: «Да здавствуют юные ленинцы Страны Советов! Ур-р-ра, товарищиц! С празником вас, с Днем Победы, с тыща второй годовщциной Великой Октябрьской революции!» (С. Майданська);

в) створення іронічного чи гумористичного ефекту, напр.: Ta ия відверта агітація на користь «made in za-bugrom» припинилась, коли громом серед ясного неба приголомиила звістка, ше Доді «ииють» звинувачення в украӥнському буржуазному начіоналізмі (С. Майданська).

Українські письменниці з практичною потребою і обдумано вживають у текстах іншомовні елементи. Інколи авторки пропонують використання паралельної моделі «іншомовне слово - лексема в українській мові». В основі такої моделі - англо-український переклад. Зі стилістичного боку вживання паралельної моделі надає експресивного заряду висловленому, має прагматичне застосування: уможливлює використання іншомовних елементів без необхідних тлумачень чи коментарів, напр.: Kaжуть, y французьких родинах популярною є так звана crise de six mois - криза шести років. Роже з Яною переживали сrise de six mois (С. Кононенко); Але Біст відповів, щзо з Дружбонародівкою він іще розбереться. $A$ їм не варто брати на себе додатковий тягар. Він так $і$ сказав: additional burden (Є. Кононенко); $A$ mут, на іншій медалі... на аверсі вгорі латинський напис, «VIRTUTE ET SAPIENTIA», щуо означає «мужність i мудрість»... (С. Майданська).

Найактивнішою є форма подання «іншомовне слово - покликання», напр.: У той день, коли нагло осиротілий Михайло зазирав чи не під кожен камінь у прибережному лузі, його Черемошне належало Румунї, де Богом $i$ цуарем для його підданих служсв король Мігай, а тут, на заміській окраӥні Romania mare, y забитому в гори селі над Черемомем, царями й Богами були королівські посередники - служиві вояки місцевої жандармерї й graniceri на чолі з лейтенантом Луполом та місцеві дідичі (М. Матіос), Romania mare - Велика Румунія (М. Матіос). Авторки складають глосарій іншомовних слів, який здебільшого подають у кінці твору. Наприклад, роман «Діти Ніоби» С. Майданської супроводжується словником, що містить слова з німецької, румунської, польської та французької мов.

У жіночій прозі транслітеровані іншомовні лексеми (ТІЛ) найпродуктивніше представлені у творчості Є. Кононенко. На нашу думку, 
саме перекладацька діяльність поповнює активний словниковий запас авторки великою кількістю іншомовної лексики, що репрезентовано в їі прозових творах, напр.: Як не повернуся з цзього вояэсу, значить так тому $i$ бути! (Є. Кононенко); Плюс шведський стіл на сніданок, різномовні меню на обіди та вечері, кава семи сортів під час кофі-брейків між засіданнями (Є. Кононенко); - Це правда, щу ти колись був ї бой-френдом? - Я мало не став ї брайд-грумом (Є. Кононенко). Наведені приклади ілюструють використання ІЛ відповідно до норм сучасної української мови: іменникамангліцизмам кофі-брейки - coffee-breaks, вояж - voyage, бой-френд - bоуfriend, брайд-грум - bride-groom [2] притаманні граматичні категорії роду, числа та відмінка: Р.в. - у перших двох лексемах із питомо українськими закінченнями іменників чоловічого роду -iв у множині й $-y$ в однині відповідно, а в решти - О.в. із закінченням -ом.

Транслітеровані іншомовні лексеми виконують власне номінативну та специфічні стилістичні функції. Наприклад, власне номінативна функція: Навіть по кількох роках життя в Мииині між розважливими, але, як нерідко видавалося Марійі, із притихлою кров'ю, людьми, зачувши з радіо чи телевізора радісний голос скрипки чи розпачливу тугу флуєра або наю, вона була би пускалася до танцъю чи співу, а може, й до плачу (М. Матіос), флуєр або най - (молд.) губний народний музичний інструмент (М. Матіос); - Хіба це не від лукавого? Хіба не кращче сказати «кол нідрей» бодай би $і$ в синагозі, але так, щуоб про це жодна душа не знала, окрім тої, до кого звертаєи свою молитву?! (М. Матіос), кол нідрей - іврит - молитва «Усі присягання» (М. Матіос); Аманда не була моєю леді-френд, але я дуже часто милувався ї̈ обличчям (Є. Кононенко); - О... Я й сам хотів написати резерч щзодо психосоціальних здобутків третіх суспільств, то мені гранта не дали... (Є. Кононенко). ТІЛ можуть використовуватися в апелятивній функції, підкреслюючи уважне, доброзичливе ставлення персонажа до свого співрозмовника, напр.: Я дам відповідь за вас, лібе фрау Шваримільх. Ви б хотіли жити у сучасній заможній Німеччині (С. Кононенко); - Не плачте, домно... - якомога лагідніше заспокоїв лейтенант, але вона вже була в сінях (M. Матіос). Основними стилістичними функціями транслітерованих іншомовних лексем $є$ а) іронічну, напр.: - Якщзо ми так будемо тринькати наш кеш, то щзо дістанеться для гіфтид діти Украӥни? (Є. Кононенко), б) іронічно-гумористична, напр.: - Ти не дочув, нас просять, щуоби ми відсіля виміталися, - наводячи лад на Микитиному «фейсі лиця», Богдан зосереджено струшував з його бороди конфеті й лелітки ... (С. Майданська).

Транслітеровані іншомовні слова створюють підгрунтя для зосередження уваги читача. Вони реалізують прагматичну мету письменниць: увиразнюють їхню творчу оригінальну манеру, демонструють відхід від усталених стереотипів письма.

Сучасні письменниці вживають ті чи ті іншомовні лексеми не лише на () Т. А. Давиденко, 2013. 
сторінках своїх творів, що, на нашу думку, допомагає глибше розкрити задум митців при змалюванні колоритних персонажів чи чужорідного середовища, у якому відбуваються події художнього твору. Літературний доробок Є. Кононенко та С. Майданської вирізняється особливим різновидом іншомовних слів - заголовком, який слугує основою іншомовного простору всього прозового твору. С. Майданська вдається до двомовної назви роману: «Сподіваюся на Тебе» або ж латинською - «In Te Speravi»; твір складається з двох частин, перша названа латиною - In Te Speravi, друга абсолютно співзвучна українською. Збірки «Зустріч у Сан-Франциско» та «Повії теж виходять заміж» Є. Кононенко містять оповідання «The very woman» та новелу «Special woman». Авторка подає заголовки англійською мовою, тим самим виокремлюючи їх ще й у змісті збірки та зосереджуючи на них увагу свого читача.

Отже, жіноча проза українських письменниць представляє різноманітні групи іншомовних лексем. Найпродуктивнішими $є$ іншомовні елементи 3 англійської, російської та французької мов. Менш чисельними є румунські, польські, німецькі та молдавські вкраплення. Поодинокими є лексеми з івриту. ІЛ вжито на позначення різних ЛСГ. Найактивнішими є ті, які безпосередньо чи опосередковано пов'язані з людиною, що підсилює антропоцентричне вживання іншомовних вкраплень у контексті прозових творів. Найчастіше іншомовні вкраплення можуть використовуватися без перекладу, рідше тлумачення подається або синонімічним рядом, або ж унизу сторінки самими письменницями. У контексті художніх творів ІЛ використовуються для прямої номінації денотата або ж для виконання додаткової стилістичної функції, як-от: мовно-національна ідентифікація героя, засіб створення жартівливого чи іронічного впливу на реципієнта тощо.

\section{Література}

1. Мельник С. М. Іншомовна лексика як джерело лексичних інновацій у художній прозі кінця XX - початку XXI століть / С. М. Мельник // Лінгвістика №2 (20). - 2010. С. $186-192$.

2. Новий англо-український українсько-англійський словник / [уклад. В. Ульянець та ін.]. - Харків : «Світовид», 2003. - 1526 с.

3. Румынско-русский словарь / [уклад. Г. Болокан и др.]. - Москва : «Русский язик», 1980. - 1592 с.

4. Сімонок В. П. Лексико-семантична рецепція іншомовної лексики в українській мовній картині світу : дис. ... д-ра філол. наук : 10.02.01 / В. П. Сімонок. - Х., 2001. - 478 с.

5. Тростогон М. А. Словник іншомовної лексики наукових та публіцистичних праць І. Я. Франка / М. А. Тростогон. - Вінниця : Континент-ПРИМ, 2001. - 96 с.

6. Українська мова. Енциклопедія / [редкол. : В. М. Русанівський та ін.]. - К. : Укр. енциклопедія ім. М. П. Бажана, 2007. - 856 с.

7. Французько-український українсько-французький словник / [уклад. В. Б. Бурбело та ін.]. - Ірпінь : ВТФ «Перун», 1996. - 528 с.

8. Шульга Д. О. Іншомовні слова в письменницькому епістолярії 20-50-х років XX ст. : автореф. дис. ... канд. філол. наук : 10.02.01 / Д. О. Шульга. - Д., 2012. - 20 с. 